\title{
Absonifibula estuarina sp. n. (Monogenea: Diclidophoridae) parasite of juvenile Cynoscion guatucupa (Osteichthyes) from southwestern Atlantic Ocean
}

\author{
Cláudia Portes Santos ${ }^{1}{ }^{+}$, Juan Tomás Timi² \\ 'Laboratório de Avaliação e Promoção da Saúde Ambiental, Instituto Oswaldo Cruz-Fiocruz, Av. Brasil 4365, 21040 -361 Rio de Janeiro, \\ RJ, Brasil ${ }^{2}$ Laboratorio de Parasitología, Departamento de Biología, Facultad de Ciencias Exactas y Naturales, Universidad Nacional de \\ Mar del Plata - CONICET, Mar del Plata, Argentina
}

Absonifibula estuarina sp. n. (Diclidophoridae, Absonifibulinae), is described from the gills of juvenile striped weakfish, Cynoscion guatucupa (Cuvier), from the southwestern Atlantic, Argentinean coast. This marine fish migrates to estuarine areas to spawn where exclusively juveniles are found parasitized; adult fish in marine water were never found to be parasitized by this monogenean. A. estuarina $s p$. $n$. is characterized mainly by the pedunculate clamps dissimilar in size, the shape of anterior jaw with sclerite 'a' attached to a sub-trapezoidal lamellate extension and fused to sclerites ' $c$ ' and ' $d$ '. It differs from Absonifibula bychowskyi Lawler \& Overstreet, 1976, the only known species of the genus, in the shape and arrangement of the genital corona, which is armed with six similar hooks disposed in circle and the sub-trapezoidal shape of lamellate extension (' $b$ '). The restriction to juvenile sciaenids is a shared feature among the Absonifibulinae indicating an estuary-dependent life cycle.

Key words: Absonifibula estuarina sp. n. - Monogenea - Cynoscion guatucupa - Argentina - estuaries

The striped weakfish, Cynoscion guatucupa (Cuvier) (= Cynoscion striatus) (Sciaenidae), is a demersal fish distributed in South American Atlantic waters, from Rio de Janeiro, Brazil, to north Patagonia, Argentina $\left(43^{\circ} \mathrm{S}\right)$ (Cousseau \& Perrotta 1998, Froese \& Pauly 2009); like other sciaenids, the striped weakfish inhabits coastal waters, including bays and estuaries during the spawning season (Cassia 1986, Cordo 1986, López Cazorla 2000).

The parasite fauna of this species is relatively wellknown throughout its distributional range (Martorelli 1992, Timi \& Etchegoin 1996, Timi et al. 1997, 2005, Santos et al. 2002, Sabas \& Luque 2003, Sardella et al. 2005), comprising at present four Monogenea species: Cynoscionicola jamaicencis Lambert \& Euzet and Hargicotyle louisianensis (Hargis) reported from Brazilian waters, an unknown species of Diclidophoridae found in fish from Argentina and Diplectanum squamatum Santos, Timi \& Gibson registered in both zones; all of them reported in fishes larger than $23 \mathrm{~cm}$ in total length (TL) (Santos et al. 2002, Sabas \& Luque 2003, Timi et al. 2005).

During a survey on the helminth parasites of juvenile C. guatucupa from coastal waters of Buenos Aires province, Argentina, a different diclidophorid monogenean was found exclusively on the gills of the smallest sciaenid fish $(\mathrm{TL}<16 \mathrm{~cm})$. Their detailed study has shown that they represent a new species, which is described herein.

Financial support: ANPCyT (PICT 02199), CONICET (112-20080100024), FAPERJ, PAPESV-Fiocruz/CNPq

+ Corresponding author: cpsantos@ioc.fiocruz.br

Received 11 March 2009

Accepted 26 May 2009

\section{MATERIALS AND METHODS}

A total of 500 juvenile specimens of stripped weakfish, C. guatucupa were examined for monogeneans. Samples were obtained at irregular intervals from 19901994 as accidental catches of prawn fishery at Mar del Plata Port $\left(38^{\circ} 08^{\prime} \mathrm{S} 57^{\circ} 32^{\prime} \mathrm{W}\right)$ following sampling schedules shown in Table.

Fish were examined immediately after capture or deep frozen in plastic bags at $-18^{\circ} \mathrm{C}$, until examination. After defrosting, each fish was measured for TL $(\mathrm{cm})$. Parasites were recovered from the gills after microscopic examination.

The worms recovered were fixed in formaldehyde solution $4 \%$ and stored in $70 \%$ ethanol, stained in Gomori's trichromic and Meyer's acetocarmine, dehydrated in an ethanol series, cleared in creosote or clove oil and mounted in Canada balsam. Illustrations were made with the aid of a drawing attachment on a Leica DM LS2 microscope. Measurements are presented in micrometres as the range, with the mean in parentheses, unless otherwise stated. The terminology used in the description of clamp sclerites follows Llewellyn (1958).

Confocal laser scanning microscopy studies were carried out using an Olympus BX51 with Fluoview version 3.2, the specimens analyzed having previously been stained with alcoholic chloride carmine. Type-specimens are deposited in the Helminthological Collection of the Museo de La Plata (CHMLP), La Plata, Argentina, and in the Helminthological Collection of Oswaldo Cruz Institute (CHIOC). Voucher specimens of Absonifibula bychowskyi Lawler and Overstreet, 1976 (CHIOC 37204 a-c) were also studied.

Host TL was compared among samples by mean of Kruskal-Wallis tests followed by a posteriori Tukey tests for unequal samples (Zar 1999). Prevalence and abun- 
TABLE

Composition of samples of juvenile Cynoscion guatucupa in different seasons and years in the Argentine sea

\begin{tabular}{|c|c|c|c|c|c|c|}
\hline \multirow{2}{*}{$\frac{\text { Season }}{\text { Spring }}$} & \multirow{2}{*}{$\frac{\text { Date }}{\text { Oct } 11990}$} & \multirow{2}{*}{$\begin{array}{c}\mathrm{n} \\
57\end{array}$} & \multicolumn{2}{|c|}{$\begin{array}{l}\text { Mean } \mathrm{TL} \pm \mathrm{SD} \\
\quad \text { (range) }\end{array}$} & \multirow{2}{*}{$\begin{array}{c}\text { Prevalence } \\
57.89\end{array}$} & \multirow{2}{*}{$\begin{array}{c}\text { Mean abundance } \\
2.02 \pm 2.39\end{array}$} \\
\hline & & & $7.04 \pm 2.05$ & $(4-14)$ & & \\
\hline Winter & Aug 131992 & 139 & $7.99 \pm 2.62$ & $(3-14)$ & 0.00 & 0.00 \\
\hline Summer & Mar 181993 & 38 & $9.05 \pm 2.03$ & $(6-14)$ & 23.68 & $1.08 \pm 2.51$ \\
\hline Summer & Feb 181994 & 137 & $15.26 \pm 4.21$ & $(3.8-23)$ & 10.81 & $0.06 \pm 0.36$ \\
\hline Autumn & Apr 151994 & 70 & $21.44 \pm 3.28$ & $(12-29)$ & 0.00 & 0.00 \\
\hline Spring & Dec 171994 & 59 & $14.84 \pm 2.19$ & $(9-17)$ & 5.08 & $0.05 \pm 0.22$ \\
\hline
\end{tabular}

TL: total length.

dance of infection were calculated following Bush et al. (1997). The effect of fish size on parasite abundance was analysed by mean of Spearmann rank correlations after pooling samples from the same season to ensure a broader range of fish size.

\section{Absonifubula estuarina sp. $\mathrm{n}$.}

(Figs 1-3)

Description - Diclidophoridae, Absonifibulinae. Body symmetrical, elongate, tapering at anterior end and enlarging to haptor level, TL 1.3-2.5 (2.0) mm, 370-650 (491) $(n=14)$ wide at ovary level. Haptor not distinctly set off from body proper with four pairs of pedunculated clamps which slightly decrease in size towards posterior end (Fig. 1A). Clamps of closed type, asymmetrical. Anterior jaw supported by fused sclerites: 'a' (a1, a2, a3, a4) with sub-trapezoidal lamellate extension (' $b$ '), fused to sclerites 'c' and 'd' (c1, c2, c3, d1, d2, d3); sclerites 'a', 'b' and proximal part of ' $c$ ' form a ring with elongate central space. Posterior jaw supported by five sclerites: two pairs of symmetrical sclerites (g1, g2, i, k) and a single median sclerite T-shaped (f) (Fig. 2A-E). First pair of clamps inverted, $125-200 \times 112-180(161 \times 140)(\mathrm{n}=13)$; second clamp $125-180 \times 105-160(150 \times 133)(\mathrm{n}=8)$; third clamp $100-160 \times 102-150(128 \times 120)(\mathrm{n}=7)$, fourth clamp $60-100 \times 55-110(76 \times 74)(\mathrm{n}=11)$. Terminal lappet 20 - $45(32)(\mathrm{n}=8)$ long with two pairs of larval hooks 13 - $18(16)(\mathrm{n}=9)$ long (Fig. 1B). Eyespots absent. Buccal suckers muscular, aseptate, 32 - $50 \times 32$ $50(42 \times 37)(\mathrm{n}=14)$. Mouth terminal. Pharynx ovoid 60 $-82 \times 40-62(72 \times 50)(n=13)$. Intestinal bifurcation at level of male copulatory organ. Intestinal ceca with lateral branches, extending into the haptor, confluent posteriorly. Testes 5 - $10(8)(n=9)$ in number, post-ovarian, intercecal. Vas deferens runs anteriorly dorsal to uterus. Male copulatory organ with genital corona $27-37 \times 25-$ $37(32 \times 32)(n=14)$ in diameter, armed with six similar hooks 13 - $15(14)(\mathrm{n}=14)$ long, curved inwards (Fig. 1C). Ovary tubular, folded, pre-testicular. Oviduct connects to genitor-intestinal canal. Uterus intercecal run medially to genital atrium. Vagina absent. Vitelline follicles extend from level of genital sac to haptor; transverse vitelline duct Y-shaped in ovarian region. Eggs fusiform with two polar filaments were damaged.
Type-host - Cynoscion guatucupa (Cuvier) (Sciaenidae) (body length 3-16 cm).

Site of infection - gills.

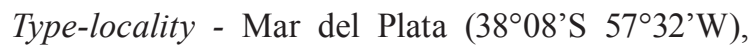
Buenos Aires Province, Argentina.

Type data and depository - Holotype CHMLP (5939) paratypes CHML (5940), paratypes CHIOC 37205 a-d.

Etymology - The specific name relates to the hostparasite interaction as parasites exclusively occur in estuarine sciaenid fish.

Host-parasite data - Fish size varied significantly among samples $(\mathrm{H} 5=351.3, \mathrm{p}<0.01)$, being host from autumn 1994 larger than those from other samples $(\mathrm{p}<$ 0.01); weakfish caught in both spring and summer, 1994 were similar in size $(\mathrm{p}>0.01)$ and larger than those from previous years $(\mathrm{p}<0.01)$; finally samples from 1990 , 1992 and 1993 were homogeneous in size (all p > 0.01). Parasites occurred seasonally, being present during spring and summer only. Samples composed by smaller fish showed higher prevalence than those containing larger ones (Table). A. estuarina sp. n. was found exclusively on the gills of the smallest sciaenid fish $(\mathrm{TL}<16$ $\mathrm{cm})$. A significant decrease of abundance with increasing host size was observed for both spring $(\mathrm{Rs}=-0.55, \mathrm{p}$ $<0.01)$ and summer $(\mathrm{Rs}=-0.39, \mathrm{p}<0.01)$ samples.

\section{DISCUSSION}

The evolutionary significance of the clamp structure and the shape of the genital corona were used in the revision of Diclidophoridae proposed by Mamaev (1976) to discriminate the genera in an evolutionary tree. In this tree, Absonifibula Lawler \& Overstreet was included among the higher genera (least primitive) on account of the morphology of the clamps, with fused sclerites in the posterior dorsal jaw ('a', 'b', 'c', 'd'), a T-shaped median sclerite (Fig. $2 \mathrm{E}-\mathrm{F})$ and a genital corona with six dissimilar hooks.

The type-species of the monotypic Absonifibula, $A$. bychowskyi Lawler \& Overstreet was described from the Atlantic croaker Micropogonias undulatus (L.) from the Gulf of Mexico (Lawler \& Overstreet 1976). It was later reported from this same host in Chesapeake Bay 


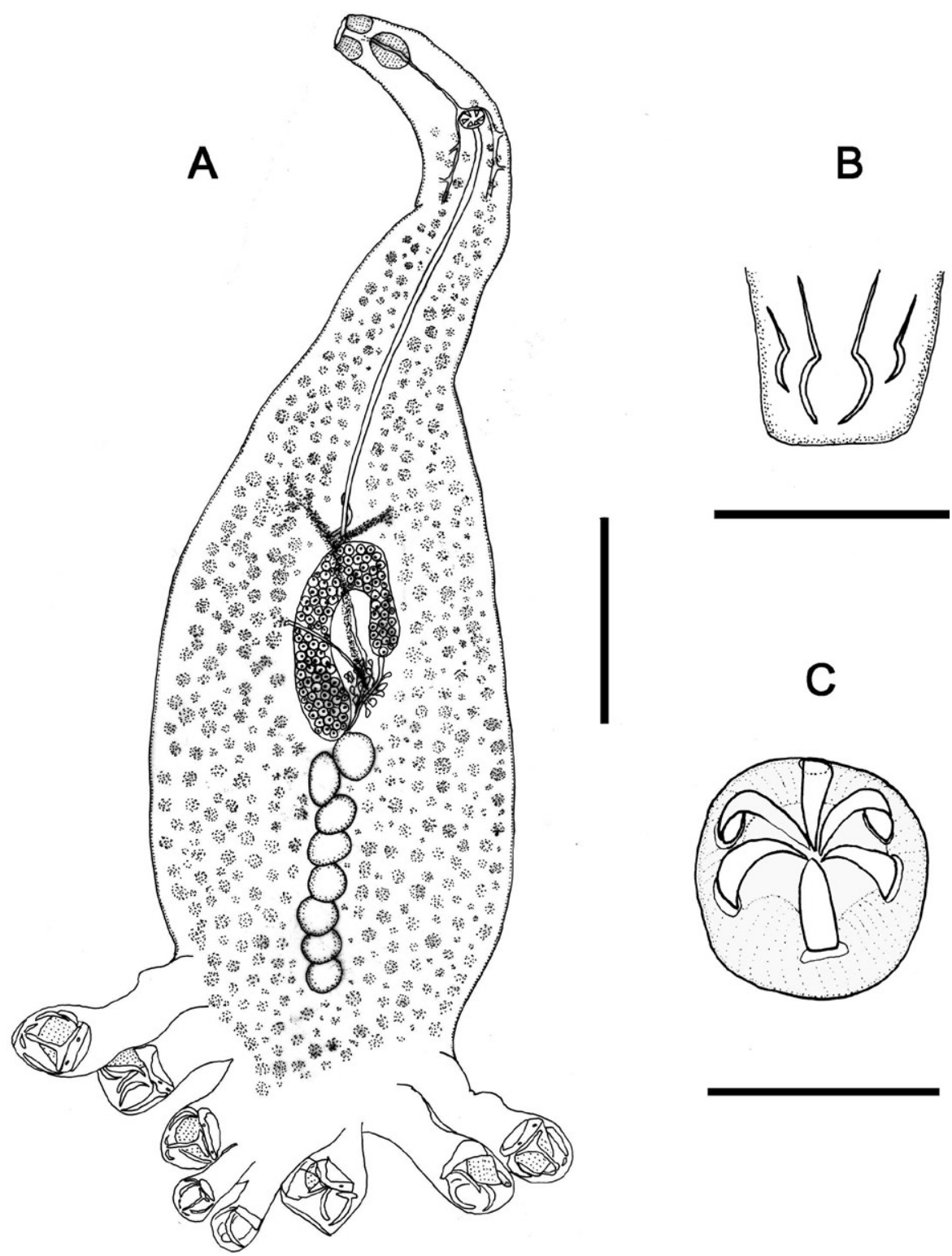

Fig. 1: Absonifibula estuarina sp. n. A: whole-mount, ventral view; B: terminal lappet with larval hooks; C: genital corona with six similar hooks. Scale bars: A $=200 \mu \mathrm{m} ; \mathrm{B}, \mathrm{C}=25 \mu \mathrm{m}$.

and Pamlico Sound (Thoney 1991, Hendrix 1994). More recently it was found in the whitemouth croaker Micropogonias furnieri (Desmarest) from mixohaline areas of the Buenos Aires Province, Argentina, and neighbouring marine environments, such as the coastal waters off Mar del Plata (Martorelli et al. 2007), where it is sympatric with the new species described above. Apparently, absonifibuline genera have an estuary-dependent life cycle, where low salinity provides a suitable condition for their transmission and survival, whereas the establishment of viable populations in marine waters seems to be impeded (Lawler \& Overstreet 1976).

A. estuarina sp. n. and A. bychowskyi show affinities in terms of their host group, which interestingly includes estuarine juvenile sciaenid fish. The main difference between these species is the shape and arrangement of the genital corona, which has six similar hooks disposed in a circle in the new species, whereas $A$. bychowskyi has six dissimilar hooks disposed in two rows, with the posterior pair being larger and directed anteriorly. Furthermore, in A. estuarina sp. n., sclerites 'a', 'b' and the proximal part of ' $c$ ' form a ring with an elongate central space and the shape of lamellate extension ('b') is more sub-trapezoidal with well marked angles. On the other hand, in A. bychowskyi, the central space of the ring ('a', 'b', 'c') is more open and elliptical and the lamellate extension is almost triangular.

A related genus to Absonifibula is Mamaevicotyle Lamothe-Argumedo, which Lamothe-Argumedo (1984) described from the serranid fish Paralabrax maculo- 
b

A

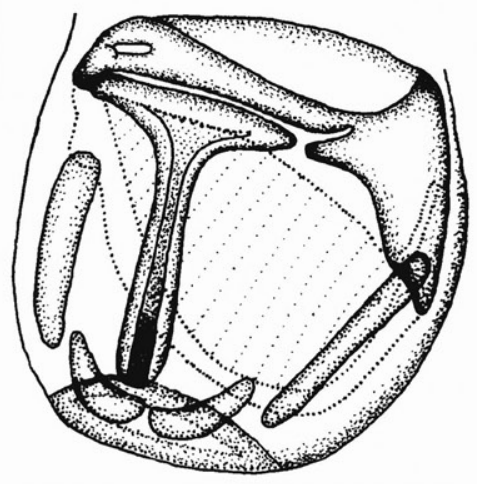

C

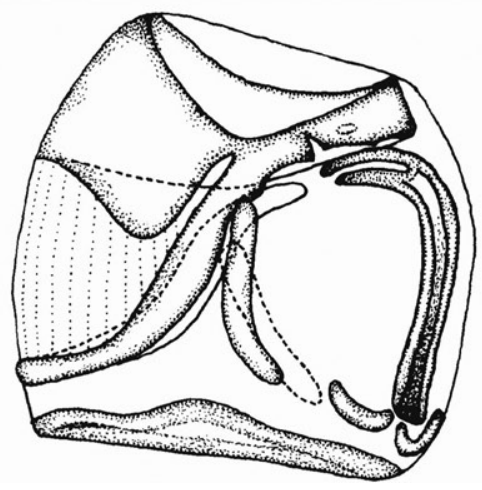

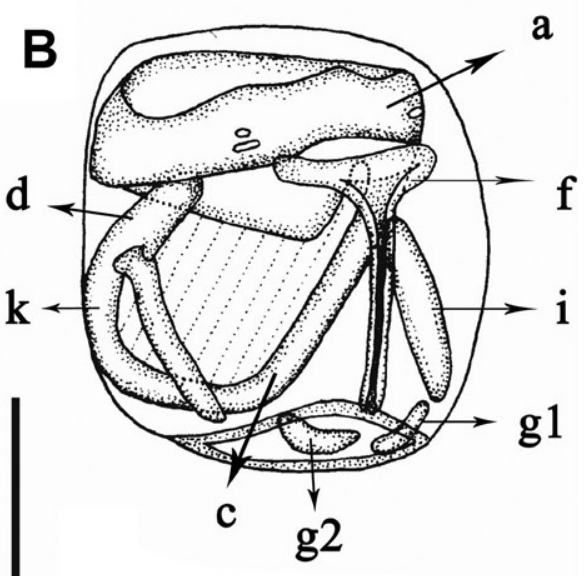

D

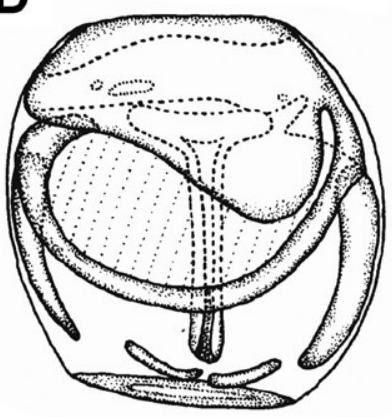

E

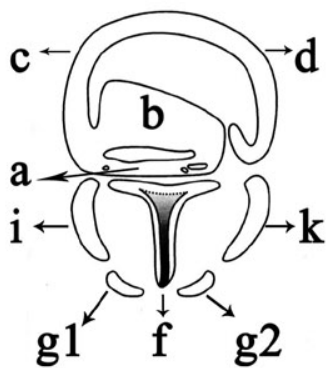

F

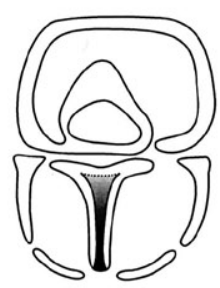

G

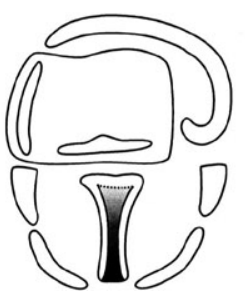

Fig. 2: Absonifibula estuarina sp. n. (A-E). A: clamp, postero-lateral view; B: clamp in postero-lateral view [median sclerite ('a'), lamellate extension ('b'), fused sclerites ('c' and 'd')], posterior jaw [median sclerite T-shaped (f), sclerites g1, g2, i and k]; C: clamp, lateral view; D: clamp, anterior view; E: schematic design of clamp with anterior jaw [ median sclerite ('a'), lamellate extension ('b'), fused sclerites 'c' and 'd'], posterior jaw [median sclerite T-shaped (f), sclerites g1, g2, i and k]; F: Absonifibula bychowskyi (schematic design of clamp sclerites); G: Mamaevicotyle (schematic design of clamp sclerites). Scale bars: A-D $=100 \mu \mathrm{m}$.

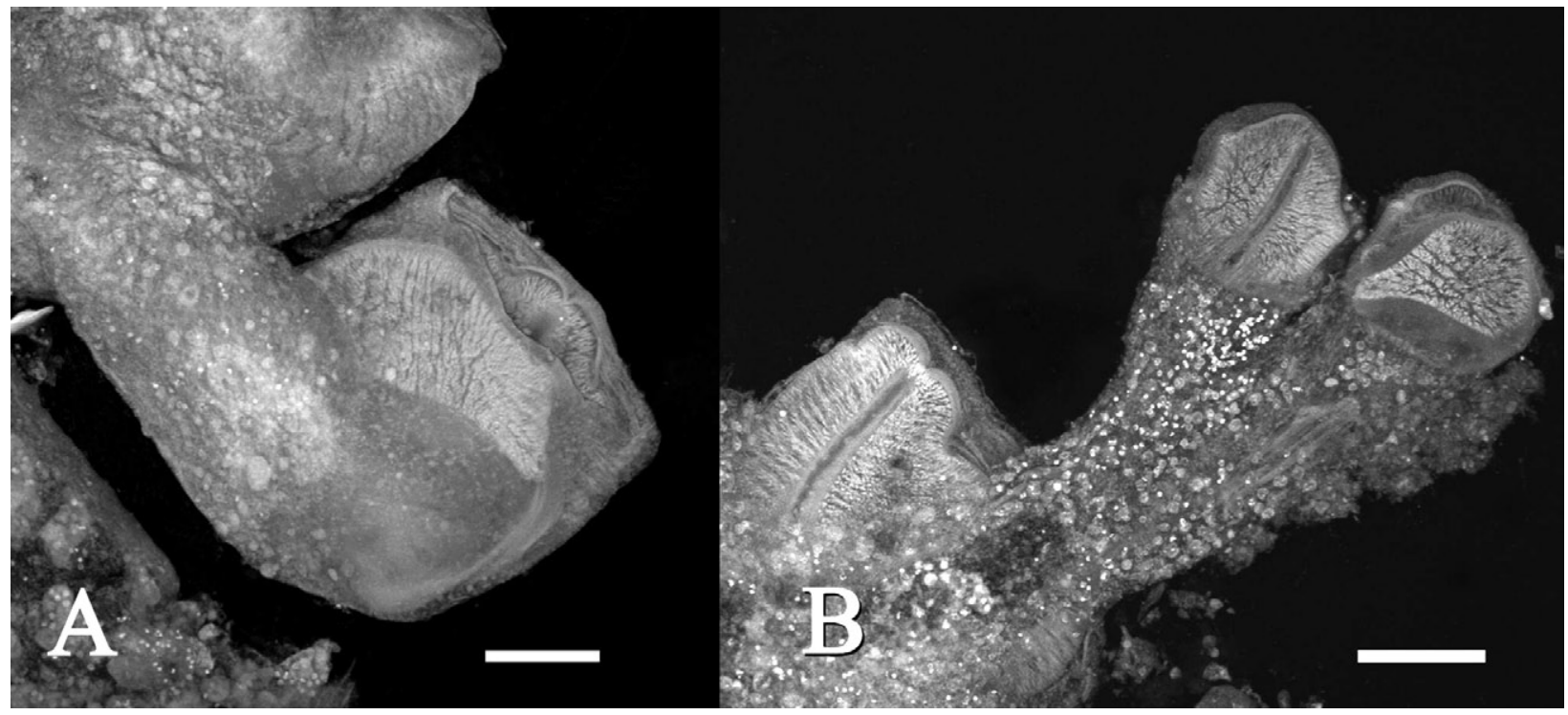

Fig. 3: Absonifibula estuarina sp. n. (confocal laser scanning microscopy). A: clamp of closed type with anterior jaw with lamellate extension and membranous part; B: larger and left smaller clamps with posterior jaw. Right smaller clamp with detail of anterior jaw. Scale bars: A, B $=50 \mu \mathrm{m}$. 
fasciatus (Steindachner) from off the Pacific coast of Mexico. Mamaevicotyle, although placed in the Diclidophorinae, resembles $A$. estuarina sp. n. in the more sub-trapezoidal shape of the lamellate extension ('b') (Fig. 2G) and the number and disposition of the genital corona spines, but sclerites ' $c$ ' and ' $d$ ' are not fused and the haptor is not pedunculate.

Specimens of $A$. estuarina sp. n. were not evenly distributed in the host population, but showed a marked seasonality and preference for younger fishes. In fact, the host size range parasitized by these monogeneans corresponds to an age of 0+ (Lopez Cazorla 2000, Sardiña \& Lopez Cazorla 2005). Both variables affecting the distribution of the new species in the host population, namely season and host size, are correlated with each other.

C. guatucupa is a coastal species inhabiting offshore waters, which migrates to estuarine and other protected areas to spawn (Sardiña \& López Cazorla 2005); juveniles remain in these areas during their first year (Lopez Cazorla 2000). Environmental factors in nursery areas, mainly salinity and temperature, are determinants of age-class abundance along the estuarine-marine gradient, with the youngest age-classes decreasing proportionally from brackish to marine waters (Jaureguízar et al. 2006).

This fish is a typical species of the inner coastal shelf waters of the mouth of the Rio de la Plata, which is characterized by low salinity and a high bottom temperature (Jaureguízar et al. 2006). The Rio de la Plata estuary dominates the coastal oceanographic conditions on the northern Argentinean sea (Acha et al. 2008), where the surface salinity distribution is controlled by the balance between onshore and offshore winds, the river discharge and the Coriolis force. As a result of the combined effects of these forces, two periods can be identified as affecting the salinity distribution. Autumn-winter is characterized by a balance between onshore and offshore winds and a maximum in the continental drainage, generating a main NNE drift of the estuarine waters along the Uruguayan coast. During spring-summer, onshore winds become dominant, resulting in a surface drift introducing freshwater southwards along the Argentine coast (Guerrero et al. 1997). This seasonal northeast/southwest oscillation implies that the coastal area around Mar del Plata falls under the influence of estuarine waters during warmer seasons (Lucas et al. 2005). This could explain the absence of monogeneans during autumn-winter, when the sampling zone is occupied by saline and colder continental shelf waters penetrating from the southwest (Jaureguizar et al. 2006).

On the other hand, a clear effect of host size on parasite burdens was observed. In fact, this parasite was never recorded in adult weakfish from either Argentina or Brazil (Sabas \& Luque 2003, Timi et al. 2005). This restriction to juvenile sciaenids is a shared feature with $A$. bychowskyi (Lawler \& Overstreet 1976, Martorelli et al. 2007). Several processes, such as changes in biochemistry and decreasing population density as fish growth and an increasing water salinity when fish migrate from estuarine to marine environments, have been pointed as causes of the lower parasite burden in older croakers (Lawler \& Overstreet 1976, Martorelli et al. 2007).
A similar combination of factors could be responsible for the observed host size-related patterns of distribution of parasite populations.

A. estuarina sp. $\mathrm{n}$. is the second species of the genus to be described from the coastal areas of the Atlantic, confirming the predilection of absonifibulines for juvenile sciaenids in estuarine areas.

\section{ACKNOWLEDGEMENTS}

To Dr. Robin Overstreet, of the Gulf Coast Research Laboratory, for kindly providing voucher specimens of Absonifibula bychowskyi for study and made valuable suggestions, for Dr. David Gibson, from Natural History Museum, for the valuable suggestions and the English revision, to Dr. Marcelo Pelajo, Pedro Paulo de A Manso and Bernardo Pascarelli, from Instituto Oswaldo Cruz, for providing the confocal facilities and MSc Rodolfo Cunha, for assisting with drawings.

\section{REFERENCES}

Acha EM, Mianzán H, Guerrero R, Carreto J, Giberto D, Montoya N, Carignan M 2008. An overview of physical and ecological processes in the Rio de la Plata. Cont Shelf Res 28: 1579-1588.

Bush AO, Lafferty KD, Lotz JM, Shostak AW 1997. Parasitology meets ecology on its own terms: Margolis et al. revisited. J Parasitol 83: 575-583.

Cassia MC 1986. Reproducción y fecundidad de la pescadilla de red, Cynoscion striatus. Publ Com Tec Mix Fr Mar 1: 191-203.

Cordo HD 1986. Estudios biológicos sobre peces costeros con datos de campañas de investigación realizadas en 1981. III. La pescadilla de red (Cynoscion striatus). Publ Com Tec Mix Fr Mar 1: $15-27$.

Cousseau MB, Perrotta RG 1998. Peces marinos de Argentina. Biología, distribución, pesca, Instituto Nacional de Investigación y Desarrollo Pesquero, Mar del Plata, 163 pp.

Froese R, Pauly D 2009. FishBase, version 01/2009. Available from: www.fishbase.org.

Guerrero RA, Acha EM, Framinan MB, Lasta CA 1997. Physical oceanography of the Río de la Plata Estuary, Argentina. Cont Shelf Res 17: 727-742.

Hendrix SS 1994. Marine flora and fauna of the Eastern United States. Platyhelminthes: Monogenea. NOAA Tech Rep NMFS 121: 1-107.

Jaureguízar AJ, Ruarte C, Guerrero RA 2006. Distribution of ageclasses of striped weakfish (Cynoscion guatucupa) along an estuarine-marine gradient: correlations with the environmental parameters. Est Coast Shelf Sci 67: 82-92.

Lamothe-Argumedo R 1984. Monogéneos de peces IX. Un genero y species nuevos de la familia Diclidophoridae del Golfo de California, Mexico. An Inst Bio Univ Nal Auton México, Ser Zoología 55: $73-84$.

Lawler AR, Overstreet RM 1976. Absonifibula bychowskyi gen. et sp. nov. (Monogenea: Absonnifibulinae subfam nov) from the Atlantic croaker, Micropogon undulates (L.) from Mississippi, USA. Proc Inst Biol Pedol, Far-East Sci Centre, Acad. Sci USSR, New Serie 34: 83-91.

Llewellin J 1958. The adhesive mechanisms of monogenetic trematodes: the attachment of species of the Diclidophoridae to the gills of gadoid fishes. J Mar Biol Ass United Kingdom 37: 67-79.

Lopez Cazorla A 2000. Age structure of the population of weakfish Cynoscion guatucupa (Cuvier) in the Bahía Blanca waters, Argentina. Fish Res 46: 279-286. 
Lucas AJ, Guerrero RA, Mianzán HW, Acha EM, Lasta CA 2005. Coastal oceanographic regimes of the Northern Argentine Continental Shelf (34-43 ${ }^{\circ}$ S). Est Coast Shelf Sci 65: 405-420.

Mamaev YL 1976. The system and phylogeny of monogeneans of the family Diclidophoridae. Trudy biol-pochvenn Inst, Vladivostok N.S. 35: 57-80.

Martorelli SR 1992. Parasites of commercial shrimps and fishes in Argentine sea: on the adult and metacercaria of Opecoeloides feliciae n. sp. Mem Inst Oswaldo Cruz 87: 43-48.

Martorelli SR, Sardella NH, Marcotegui PS 2007. New host, geographical records and some ecological aspect of Absonifibula bychowskyi Lawler et Overstreet, 1976 (Monogenea: Diclidophoridae) from estuarine areas of Argentina. Acta Ichthyol Pisc 37: 1-6.

Sabas CSS, Luque JL 2003. Metazoan parasites of weakfish, $C y$ noscion guatucupa and Macrodon ancylodon (Osteichthyes: Sciaenidae), from the coastal zone of the state of Rio de Janeiro, Brazil. Rev Bras Parasitol Vet 12: 171-178.

Santos CP, Timi JT, Gibson DI 2002. Diplectanum squamatum n. sp. (Monogenea: Diplectanidae) from the gills of Cynoscion guatucupa (Sciaenidae) in Southwest Atlantic waters. Syst Parasitol 52: 199-204.

Sardella NH, Mattiucci S, Timi JT, Bastida R, Rodríguez D, Nascetti G 2005. Corynosoma australe Johnston, 1937 and C. cetaceum Johnston \& Best, 1942 (Acanthocephala: Polymorphidae) from marine mammals and fish in Argentinean waters: genetic differentiation and taxonomic status. Syst Parasitol 61: 143-156.

Sardiña P, Lopez Cazorla A 2005. Feeding interrelationships and comparative morphology of two young sciaenids co-occurring in the South-western Atlantic waters. Hydrobiol 548: 41-49.

Thoney DA 1991. Population dynamics and community analysis of the parasite fauna of juvenile spot, Leiostomus xanthurus (Lacepede) and Atlantic croaker, Micropogonias undulatus (Linnaeus), (Sciaenidae) in two estuaries along the middle Atlantic coast of The United States. J Fish Biol 39: 515-534.

Timi JT, Etchegoin JA 1996. A new species of Lernanthropus (Copepoda: Lernanthropidae) parasite of Cynoscion striatus (Pisces: Sciaenidae) from Argentinean waters and new records of Lernanthropus trachuri. Folia Parasitol 43: 71-74.

Timi JT, Luque, JL, Sardella NH 2005. Parasites of Cynoscion guatucupa along South American Atlantic coasts: evidence for stock discrimination. J Fish Biol 67: 1603-1618.

Timi JT, Navone GT, Sardella NH 1997. First report and biological considerations of Dichelyne (Dichelyne) spinicaudatus (Nematoda: Cucullanidae) parasite of Cynoscion striatus (Pisces: Sciaenidae) from the South West Atlantic Ocean. Helminthol 34: 105-111.

Zar JH 1999. Biostatistical analysis, 4th ed., Prentice-Hall Inc, Englewood Cliffs, New Jersey, 929 pp. 